Article

\title{
Applying the SDGs to Cities: Business as Usual or a New Dawn?
}

\author{
Roland Zinkernagel ${ }^{1,2, *}$, , James Evans ${ }^{3}$ and Lena Neij ${ }^{1}$ \\ 1 International Institute for Industrial Environmental Economics, Lund University, P.O. Box 196, \\ 22100 Lund, Sweden; lena.neij@iiiee.lu.se \\ 2 Environment Department, City of Malmö, 20580 Malmö, Sweden \\ 3 Department of Geography, University of Manchester; Oxford Rd, Manchester M13 9PL, UK; \\ james.z.evans@manchester.ac.uk \\ * Correspondence: roland.zinkernagel@iiiee.lu.se; Tel.: +46-708-120227
}

Received: 28 June 2018; Accepted: 5 September 2018; Published: 7 September 2018

check for updates

\begin{abstract}
With growing urbanisation the sustainability of cities has become increasingly important. Although cities have been using indicators for a long time it is only in the last decades that attempts have been made to collate indicators into sets that reflect the many different aspects required to assess the sustainability of a city. The aim of this paper is to review the evolution of indicators for monitoring sustainable urban development in order to understand how 'new' the indicators suggested by the UN Sustainable Development Goals (SDGs) are for cities and the challenges they may face in using them. The review reveals that previous indicator sets emphasised environmental sustainability, health and economic growth. It is also shown that indicator sets that pre-date the SDGs lacked dimensions such as gender equality and reduced inequalities. In all, the SDG indicators provide the possibility of a more balanced and integrated approach to urban sustainability monitoring. At the same time, further research is needed to understand how to adapt the SDGs, targets and indicators to specific urban contexts. Challenges of local application include their large number, their generic characteristics and the need to complement them with specific indicators that are more relevant at the city level.
\end{abstract}

Keywords: sustainable development goals; urban sustainable development; indicators; evolution of sustainability assessment

\section{Introduction}

Cities have become important agents for sustainability. Agenda 21, adopted at the 1992 Rio Earth conference, enshrined the active involvement of local stakeholders in delivering sustainable development, giving cities a key role in sustainability efforts [1-3]. In more recent years, cities have actively engaged in the UN climate negotiations, asking for and committing to greenhouse gas mitigation targets $[2,4,5]$. At the same time, cities are facing many challenges, such as containing urban sprawl [6,7], limiting greenhouse gas emissions [8,9], ensuring satisfactory and sustainable water supply, providing adequate waste management and improving human health $[6,10,11]$.

Cities have a key role to play in accelerating sustainable development $[3,12-14]$. A total of $66 \%$ of the world's population is expected to live in cities by 2060 [15], and rapid urbanisation puts a huge strain on urban systems [16,17]. It has become increasingly important to monitor cites' performance in reaching sustainability. As urban systems are complex, a common way to simplify monitoring is the use of indicators [18]. An indicator can be defined as an observable feature that is assumed to represent a state or a trend, usually an unobservable one, at a certain point in time [19,20]. Cities have been and are using indicators to a larger or lesser degree to assess social issues [21,22] and environmental conditions [23] as well as economic development [22]. During the last two decades there have been 
many attempts by international organisations and cities themselves, as well as private and interest groups, to develop indicators and indicator sets to monitor cities' sustainable development [24], accompanied by a proliferation of different monitoring methods [12,25].

Based on the experience of the Millennium Development Goals (MDG) [26,27], the UN adopted the Sustainable Development Goals (SDGs) in the autumn of 2015, in order to provide guidance for all countries and all stakeholders to achieve sustainable development [28]. The SDGs comprise 17 goals covering different aspects of sustainable development, as defined by the Brundtland commission [29,30]. These goals in turn consist of 169 targets and several hundred indicators [31] to assess progress in meeting the goals (at the time of writing, the number of SDG indicators is 230, of which nine are repeated twice or three times [32]).

Since the introduction of the SDGs, a growing body of literature has dealt with various aspects regarding the historical evolution of the SDGs $[29,33,34]$, as well as the degree to which the SDGs themselves can facilitate more sustainable development [26,29,30,35-37] through their application to different levels and contexts.

The SDGs have been adopted by the UN as goals to be reached by 2030 in order to enhance sustainable development globally. The SDG indicators are meant to monitor progress towards achieving these goals. In the process of implementing the SDGs, emphasis shifts from the goals themselves towards monitoring and assessing progress towards achieving them [38,39]. Inevitably, at local level, cities use the goals as frameworks for their own sustainability performance.

There is an increasing amount of research dealing with aspects regarding the use of the SDGs in cities $[3,16,38,40-49]$. Guides on localising the SDGs are starting to become available [50,51]. Several goals directly address the local level, not least goal 11 (sustainable cities and communities). However, a number of researchers have noted that cities and urban activities touch upon the majority of all 17 goals $[3,43,45]$. Recent research has highlighted a number of challenges encountered when implementing the SDGs at a local level. The core challenges identified in the literature are summarised below:

- Availability of reliable data in cities [40,44-46,49]. The number of suggested SDG indicators makes it difficult meet the required demand on data.

- Policy relevance in the local context and political prioritisation process [3,33,38,48,52]. Political prioritisation can simplify, but also jeopardise successful implementation of the SDGs by focusing too much on locally relevant aspects.

- Covering the complexity of urban systems $[12,38,44,48]$. Local governments deal with many aspects that are interdependent; local implementation of the SDGs will lead to the identification of synergies, but also contradictions in goal achievement.

- Dealing with out-of-boundary challenges and externalities [48,53-55]. Cities not only have an impact within their territories but also elsewhere, leading to challenges in allocating those impacts.

- Indicators in a multilevel and multi-actor governance structure $[3,56,57]$. Several aspects might need to be addressed at different levels and with different actors, depending on the governance structure in each country, including who is responsible for monitoring these aspects. The challenge lies in identifying which level has what responsibility as well as establishing and operationalising cooperation.

- Capacity and skills in academic and practitioner fields $[3,33,48,56]$. More knowledge and experiences needs to be gained to be able to use the SDGs in practice as a tool to achieve sustainable development.

All of this means that, even though the SDGs offer a new opportunity to assess cities' sustainability performance at all levels, it is not clear what benefits or barriers exist with regard to implementing SDGs in cities, the extent to which the SDGs will improve the assessment of the sustainability of a city, or how cities actively contribute and get involved in the global challenge of reaching sustainability $[3,58]$. This paper contributes to addressing these issues. 
The SDGs have progressed from the original division of sustainability aspects into various pillars to acknowledge the complexity and interrelatedness of development [59]. They require holistic and coordinated actions across sectors, illustrated by goal 17, which focuses on enabling actions.

The objective of this paper is to review indicator sets previously developed to evaluate the progress of sustainability in cities, with the purpose of identifying: (1) which are the most commonly used indicators so far; (2) the degree to which the most commonly used indicator sets cover various aspects of sustainable development; and (3) how previously used indicator sets compare with the indicators suggested by the SDGs. The answers to these questions are used to place the SDGs in a chronological context and to analyse the new aspects that the SDG indicators are introducing to monitor the achievement of the goals, and in turn in evaluating sustainability in cities, whether the SDG indicators match the challenges that cities face today, and some of the challenges they may present to cities in terms of operationalisation. The results of this study will be valuable for cities implementing the SDGs at the local level and will contribute to the emerging academic debate by outlining a detailed research agenda to facilitate the implementation of the SDGs at the city level.

The remainder of this paper is organised as follows: Section 2 discusses the use of indicators in general and in assessing urban sustainability, and also provides an outline of the selection of indicator sets included in the analysis of this study; Section 3 analyses the data collected in order to identify trends in the past evolution of sustainability monitoring, how well the concept of sustainable development has been captured, and to compare previous indicators with the ones contained in the SDGs; and the paper concludes with a discussion of the challenges for cities and key areas for future research.

\section{Seeing the Forest for the Trees? Background and Methodological Approach to Analyse Indicators for Sustainable Urban Development}

\subsection{Conceptual Background: Sustainability Indicators and the Complexity of Urban Systems}

The following section presents the main methodological and conceptual background for identifying and using indicators for monitoring urban sustainable development as identified in the literature. The section summarises key epistemological views on indicator use as well as criteria for indicator selection, and contrasts these with the actual selection process that cities implement.

Monitoring development through indicators is regarded as an efficient and meaningful way to condense complex system dynamics into a manageable amount of information that can be used to assess progress against stated outcomes [60]. Part of the research community argues for a selection of indicators based on conceptual frameworks describing the interrelation between human systems and ecosystems. These frameworks are meant to help with structuring the diversity of activities and interactions and thus make it possible to identify and prioritise how to monitor sustainable development [22,26,61,62], thereby aiding the process of selecting indicators [63]. Nevertheless, the use of frameworks has been criticised for having been developed mostly through a top-down and technically-dominated approach, not necessarily considering practical feasibility or use, especially when aiming to monitor sustainable development $[18,22,61]$.

Literature on indicators in general, as well as literature on indicator use in the urban context, states that sustainability indicators are used to monitor change in society and to show progress towards a given goal or objective based on observable or measurable markers (indicators) $[17,20,24,64,65]$. By monitoring the same indicator over time it is possible to identify trends and development directions [66]. Indicators can be used to monitor both quantitative and qualitative changes in society [64].

The setting of indicators can either be theoretical and science-driven-in which case the indicators are seen as non-subjective tools where the selection of indicators is based on theoretical models-or value driven, where the indicators reflect current social debates and priorities. The latter practice is more often applied when indicators are used for policy-making and/or there is a need to co-produce indicators with stakeholders such as communities or residents. The reasoning is that in many cases the 
subject of analysis changes over time, and hence there is no static relationship between the underlying theoretical model and the data being produced by the indicators based on the model [67].

When choosing indicators, it is stressed that they should be specific, measurable or observable, and that data are, or could be, made available. However, the selection of sustainability indicators is challenging. Wilson et al. (2007) showed that different understanding of sustainability will lead to different indicators being selected, which in turn will lead to differences in the resulting sustainability performance [17]. Mori and Christodoulou (2012) reviewed sustainability indicator sets that have been used by cities, and conclude that none of these indicator sets satisfies the requirements necessary to monitor sustainable development in line with the triple bottom line in cities across the world [55].

One criterion for selecting indicators to monitor sustainable development, according to the literature, is that the total number of indicators should be limited $[17,63,68-70]$ in order to obtain a manageable workload and not get lost in too many details. Indicators must be policy-relevant, reliable, measurable, wide in scope and simple. In practice, however, indicators for sustainable urban development have been selected on the basis of political prioritisation, perceived importance and/or data availability [71-73]. Research stresses the importance of involving stakeholders in the process of selecting evaluation indicators, especially when monitoring progress towards sustainable development [18,61,64,74].

When selecting indicators, cities need to deal with the complexity of the urban system, and to decide what is regarded as representative in order to monitor trends and developments towards a goal (i.e., be sustainable), whilst the goal is in fact not clearly defined. The process of selecting and applying indicators is further complicated by the fact that the base line changes; there is no constant status quo. Consequently, what is important and prioritised, and the related indicators that are most appropriate, is constantly changing.

\subsection{Data Used in This Study}

Since the introduction of the concept of Agenda 21 in the 1990s, several international organisations have developed indicator sets to monitor progress towards the Agenda's goals (see Figure 1). Indicator sets to monitor both global and local sustainability goals have been developed by cities [64,75-77], private companies (e.g., Arcadis, the Economist Intelligence Unit) and in public-private collaboration (e.g., Sustainable Cities International). Sustainability indicator sets that have been developed for a more general level have also been applied in an urban context. Examples of these include the Ecological Footprint, Environmental Sustainability Index, Dashboard of Sustainability, Welfare Index, Index of Sustainable Economic Welfare, City Development Index, Emergy/Exergy, Human Development Index, Environmental Vulnerability Index, Living Planet Index and Environmentally-adjusted Domestic Product $[24,55,76]$.

In this paper, we analyse selected indicator sets introduced to monitor urban sustainability. The broader population of indicators was identified by collecting information about indicators for monitoring sustainability, monitoring urban development and monitoring quality of life. Based on this information, indicator sets were selected based on the following principles: (1) the indicator set aims to cover sustainability in its entirety and account for each different aspect independently; (2) the indicators were chosen on the basis that they should be developed for a wider group of interested parties and not a specific group of actors; (3) the indicators should be developed by transnational, non-private organisations to avoid country-specific bias, and therefore be able to be applicable in a wide range of different contexts; and (4) the indicators should target societal challenges and not be specifically developed to evaluate certain products or services. These selection criteria resulted in the indicator sets represented in Figure 1. Even though some of the indicator sets have not been developed to monitor urban sustainability, they have or are being used by cities for this purpose. Detailed information about the indicator sets can be found in Table 1. 
Table 1. Summary of characteristics of each of the indicator sets analysed in this paper.

\begin{tabular}{|c|c|c|c|c|c|}
\hline & Use-Phase & Launch & Adjustments & Use Frequency & Urban Aspect \\
\hline $\begin{array}{l}\text { UN Habitats Urban indicator } \\
\text { programme [78] }\end{array}$ & 1996-date & 1993 & $\begin{array}{l}1996 \\
2001\end{array}$ & Different versions are used by $200+$ cities & Strong urban focus \\
\hline $\begin{array}{l}\text { Commission for Sustainable } \\
\text { Development's Sustainable } \\
\text { Development indicators [79] }\end{array}$ & 1995-са. 2008 & 1995 & $\begin{array}{l}2001 \\
2005\end{array}$ & No information on use in cities & $\begin{array}{l}\text { Primarily focusing on national level } \\
\text { reporting on sustainable } \\
\text { development. Several aspects that } \\
\text { are relevant at local level }\end{array}$ \\
\hline EU's Urban sustainability indicators [80] & 1998-ca. 2002 & 1998 & & No information on use in cities & Strong urban focus \\
\hline European Common Indicators [81] & $2000-2004$ & 2000 & & Tested by 42 cities & Strong urban focus \\
\hline OECD's Better Life Index [82] & 2011-date & 2011 & frequent & Frequent reporting on national level & $\begin{array}{c}\text { Focus on citizens' quality of life from } \\
\text { a mainly national perspective; some } \\
\text { urban aspect are included }\end{array}$ \\
\hline $\begin{array}{l}\text { ISO } 37120 \text { indicators (Sustainable } \\
\text { development of communities) [83] }\end{array}$ & 2014-date & 2014 & & $\begin{array}{l}30 \text { cities have reported at least } \\
\text { some indicators }\end{array}$ & Strong urban focus \\
\hline $\begin{array}{c}\text { Sustainable Development Goals } \\
\text { indicators [84] }\end{array}$ & 2015 & 2015 & & No information on use in cities yet & $\begin{array}{l}\text { Sustainable development on all } \\
\text { levels in all regards }\end{array}$ \\
\hline
\end{tabular}




\begin{tabular}{|l|l|l|l|}
\cline { 2 - 3 } & $\begin{array}{l}\text { Urban } \\
\text { indicator } \\
\text { programm }\end{array}$ & $\begin{array}{l}\text { CSD indicators } \\
\text { for SD }\end{array}$ & $\begin{array}{l}\text { Millennium } \\
\text { Goal } \\
\text { indicators }\end{array}$ \\
\hline
\end{tabular}

\section{Sustainable Development Goal indicators}

EU $\quad$\begin{tabular}{|l|} 
Urban \\
sustainability \\
indicators
\end{tabular}

OECD

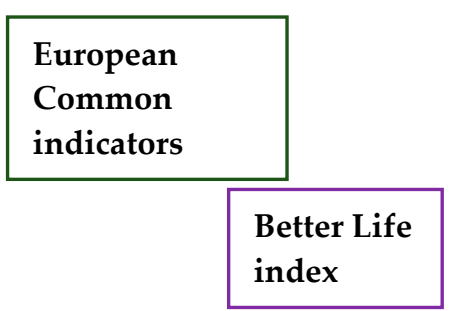

Figure 1. Chronological development of selected indicator sets by international organisations since the 1990s included in this study. The Millennium Development Goals are marked in grey as they do not make a claim to cover sustainability; however, they are an important link to the development of the Sustainable Development Goals.

In the present analysis, the studied indicator sets are assessed in relation to the SDG indicator set, which is built on the experiences and strategies of previous goals and indicators-in particular the Millennium Development Goals [27,29,45,85,86], which acknowledge and address the need to explicitly include all dimensions of sustainability, set globally relevant goals and include local government. In particular, the recognition of the role of urban areas and local governments in facilitating sustainable development has led to the inclusion of a specific urban goal dedicated to cities and communities [45], even though many of the other 16 goals also touch upon urban issues $[3,43,50]$ and many cities already have their own sustainability goals.

\section{Analysis of Sustainability Monitoring in Cities: Increasing Complexity Means That More Indicators Need to Be Managed}

The following section reviews and discusses which aspects have been most commonly monitored since the development of indicator sets for urban sustainable development began. The various indicator sets in this study are assessed with regard to the extent to which they cover sustainability, and to which they contrast with each other and with the indicators suggested by the SDGs. The section concludes with an analysis of the SDG indicators and of how suitable they appear to be for evaluating sustainability in cities, both from a theoretical perspective and in practical terms.

\subsection{Challenges in Measuring the Undefined}

Despite the recommendations of limiting the total number of indicators [68-70], there is a trend towards an increasing number of indicators. Whereas earlier indicator sets had a relatively small number of indicators (Urban Sustainability Indicators: 15; UN Habitat Urban indicator guidelines: 38; European Common indicators: 10; CSD Indicators for sustainable development: 49; Better Life Index: 24), newer indicator sets contain far higher numbers of indicators (ISO 37 120: 97; SDGs: 230). This reflects the fact that more indicators are needed in order to be able to display all different aspects of sustainability. At the same time, the increasing number of indicators exacerbates the challenges of data availability and reliability in cites. The higher the number of indicators, the more difficult and work intensive it is to collect the information; voices have already been raised pointing out that only geographically relevant indicators need to be reported [28], even though the UN statistical division 
asks for reporting on all indicators at a national level [87]. Whereas earlier indicator sets limited the total number of indicators, thus making it more feasible to collect all information that had been deemed relevant, newer indicator sets, and in particular the SDG indicators, pose big challenges (Simon et al., 2016). The number of indicators therefore needs to strike a balance between the existence of reliable data and the complexity of urban systems, ideally including aspects of boundary challenges and externalities.

Increasing indicator numbers affect a number of the abovementioned challenges positively or negatively, as outlined in Table 2.

Using indicators to inform policies at the local level entails a number of different challenges. Depending on the local conditions and governance structure in each country and/or region, cities might have more or less capacity to influence local conditions through policy intervention [3]. Consequently, the relevance of indicators from a policy intervention perspective is not necessarily straightforward and is valid for any type of indicator set that has been developed for an international context. The same is the case in a regime of multi-level and multi-actor governance, a situation that is widely expected to become more rather than less prevalent in the future $[88,89]$. With an increasing number of actors that either influence or are needed to be able to report indicators, it is becoming more and more important that the choice of indicators reflects and acknowledges this trend and the associated challenges and opportunities of working with a wide range of stakeholders to monitor and report.

The risk of politically-steered prioritisation of policy interventions that are not based on evidence (delivered by indicators), as mentioned by Keirstead and Leach (2008) and Shen et al. (2011), is assumed in principle to be equally high across all indicator sets [71,72]. When coupled with the increasing total number of indicators, however, it could be argued that politically-led prioritisation increases with an increasing number of indicators, as it can be legitimised as a way to keep monitoring at a more manageable level. At the same time, it could also be misused and lead to a prioritisation of areas that are predominantly of special interest in political debates.

\subsection{What Matters Most: Stable and Evolving Aspects in Monitoring Sustainability}

The following section gives an overview of the aspects that have been stable in sustainability assessments since they gained momentum in the 1990s. Table 3 presents the most common aspects that are covered over time by indicators in the selected sets that appear in more than half of all analysed indicator sets. Other aspects are less consistent over time and can be assumed to reflect topical attention at the time the respective indicator set was developed. It is worth noting that all these indicators are reflective indicators in themselves, i.e., measuring the current state. It is only by relating these to each other, i.e., the summary of the indicators, that it is possible to give a bigger picture on the state of, for example, the environment in general. Interestingly, the list contains only one indicator associated with economic aspects; overall, environmental and social aspects dominate. This economic indicator (unemployment rate) has, however, a very strong social implication. 
Table 2. Positive and negative effects of each identified challenge regarding the implementation of SDGs at local level.

\begin{tabular}{lll}
\hline \multicolumn{1}{c}{ Identified Challenges } & \multicolumn{1}{c}{ Negative } \\
\hline Access to reliable data & $\begin{array}{l}\text { Difficult to gather data of sufficient quality for } \\
\text { all indicators }\end{array}$ & $\begin{array}{l}\text { More chance of being able to collect data for some indicators } \\
\text { and opportunity to engage wider range of stakeholders }\end{array}$ \\
\hline Policy relevance and political prioritisation & $\begin{array}{l}\text { Risk that groups of indicators are ignored if defined as } \\
\text { non-applicable for political reasons }\end{array}$ & $\begin{array}{l}\text { Possibility to choose indicators that are policy-relevant at } \\
\text { local level }\end{array}$ \\
\cline { 1 - 2 } Capturing the complexity of the urban system & $\begin{array}{l}\text { Despite the large number of indicators, } \\
\text { interrelationships, interdependencies and synergies are } \\
\text { not highlighted or considered }\end{array}$ & $\begin{array}{l}\text { The higher the number of indicators the higher the likelihood } \\
\text { of being able to capture complexity }\end{array}$ \\
\hline Covering out of boundary challenges and externalities & $\begin{array}{l}\text { Difficult for cities to generate data covering } \\
\text { these elements. }\end{array}$ & $\begin{array}{l}\text { The higher the number of indicators the greater the likelihood } \\
\text { of covering out of boundary challenges and externalities. }\end{array}$ \\
\cline { 1 - 2 } Acting in a multilevel and multi-actor governance system & $\begin{array}{l}\text { A number of indicators are targeting levels other than } \\
\text { the urban level }\end{array}$ & $\begin{array}{l}\text { Possibility of capturing issues that influence the urban level but } \\
\text { are dealt with at other levels }\end{array}$ \\
\hline Availability of capacity and skills & $\begin{array}{l}\text { The higher the number of indicators, the higher the } \\
\text { need for skills in more areas of expertise and the higher } \\
\text { the need for capacity }\end{array}$ & $\begin{array}{l}\text { Involving other competences and other actors will result in } \\
\text { better cooperation and increased capacity across sectors }\end{array}$ \\
\hline
\end{tabular}


Table 3. Most common indicators used in the analysed indicator sets *.

\begin{tabular}{cc}
\hline Indicators That Appear Most Frequently & Frequency of Use (n = 7 Indicator Sets) \\
\hline Education amongst children and young people & 6 \\
Air quality (particulate matter) & 6 \\
Victims of homicide & 5 \\
(Un)employment rate & 5 \\
Access to sanitation & 4 \\
Under 5 mortality rate & 4 \\
Safely managed drinking water & 4 \\
Greenhouse gas emissions & 4 \\
Access to electricity and use per capita & 4 \\
Hazardous waste generated and treated & 4 \\
Voter participation in elections & 4 \\
\hline * Urban indicator programme, CSD indicator for sustainable development, ISO 37 120, Urban sustainability \\
indicators, European Common indicators, Better Life index, SDG indicators.
\end{tabular}

The indicators relating to air quality and to employment/unemployment rate have been used over the longest time span; they can be found in the earliest indicator set from 1998 and have been used in most sets since then. The indicator relating to greenhouse gas emissions per capita was used early on but is missing among the SDG indicators. The same is the case for the indicator relating to voter participation in municipal elections. The indicator relating to hazardous waste is one where it is possible to see a clear trend indicating an increasing attention in more recent years. For other indicators in Table 2 it was not possible to determine clear chronological patterns.

The analysis of the full data set suggests that the following aspects were regarded as more important initially but have lost importance over the years: modal split of transportation, total water consumption per capita, housing according to building regulations, urban population growth and proportion of households with more than three persons per room. On the contrary, indicators that have gained importance over the years are: proportion of urban population living in slums, proportion of teachers having received adequate training, passengers and freight volumes and internet connections.

It is worth noting that the use of indicators has been changing over time, in line with an increasing trend to incorporate 'New Public Management' ideals into public administration, i.e., the ideals of cost-efficiency, decentralisation, customer-orientation and empowerment. The desire to achieve greater economic efficiency through closer management and monitoring is reflected in the choice and use of indicators in the public sector [64,67]. In all, indicators have moved towards an approach that is more centred on the individual and quality of life. Instead of measuring total water consumption, for example, indicators intend to cover the proportion of the population that has access to safe drinking water or sanitation.

\subsection{Evolution of Sustainability Monitoring}

The analysis reveals that indicator sets have until now each been used only over a certain time period, after which they have been developed and adjusted. This indicates that there has been a tendency towards following new trends and shifts in (political) prioritisation over the years. This might be explained by the lack of a common definition of sustainability or sustainable cities [54].

Figure 2 gives an overview of the total number of indicators suggested by various indicator sets, grouped according to the structure proposed by the SDGs. It becomes obvious that the number of indicators suggested to implement the SDGs is by far the highest-232 indicators in total-going beyond other assessment tools in all but two of the 17 goals. Only the ISO 37120 indicators surpass the number of SDG indicators on the topics of goal 7 (affordable and clean energy) and goal 11 (sustainable cities and communities). The high number of indicators with the ISO standard for goal 11 could be explained by the fact that this standard focuses on smart city data, i.e., collecting data necessary for the 
efficient running of a city, although the standard still claims to centre on evaluating the sustainability of cities.

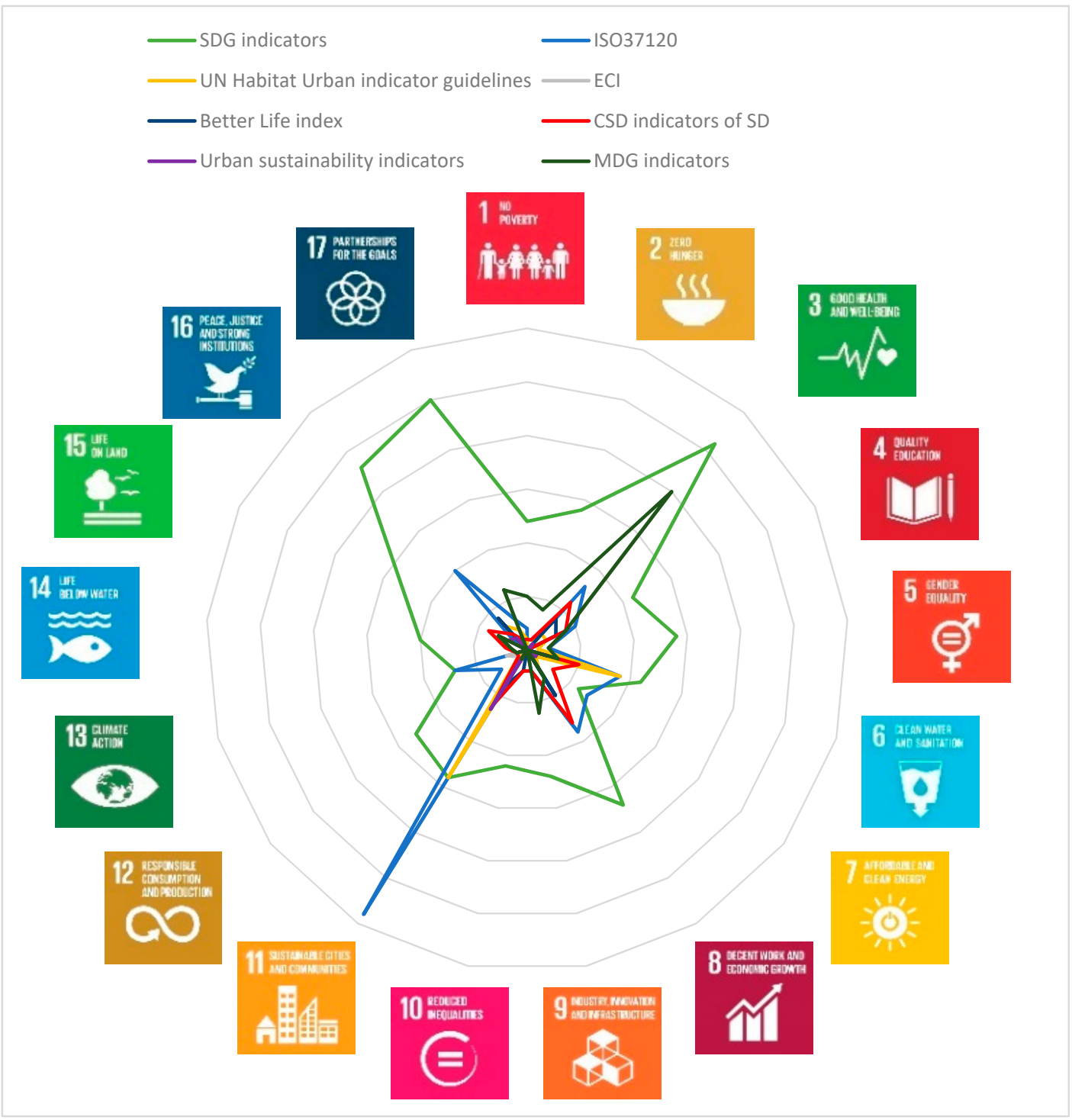

Figure 2. Number of indicators in different sustainability assessments according to SDG structure.

Figure 2 also shows the relation between the number of indicators for the SDGs and the Millennium Development Goals (MDGs). The MDGs were developed as a global effort to improve the quality of life of people, especially those in the developing world. Although they did not specifically make any claim to cover all aspects of sustainable development, the process of developing the MDGs, as well as the effort of reaching the goals, has had a great impact on the way that the SDGs have been developed, in particular by acknowledging the need to cover all aspects of sustainability, including possible synergies and contradictions between the different goals [26,27]. As Figure 2 shows, both SDGs and MDGs have a strong focus on health and wellbeing (SDG goal 3) and partnership and cooperation (SDG goal 17). What also becomes apparent is the increased focus on gender equality (SDG goal 5), economic development (SDG goal 8), sustainable cities and communities (SDG goal 11) and sustainable production and consumption (SDG goal 12). This clearly indicates an evolution towards a more holistic approach.

Furthermore, Figure 2 indicates that there are a number of 'hot spots', i.e., goals, that have received more attention than others. Theses hot spots are goal 3 (good health and wellbeing), goal 6 (clean water 
and sanitation), goal 8 (decent work and economic growth), goal 11 (sustainable cities and communities) and goal 16 (peace, justice and strong institutions). These five topics receive higher indicator counts throughout the indicator sets, even when disregarding the SDG indicators. The accumulation of indicators under some aspects, and consequentially the gaps arising under other aspects in the six pre-2015 indicator sets, indicate that sustainability is covered only to a varying degree during that period. This is confirmed by the work of Luederitz et al. using a cluster analysis of scientific literature on the sustainability performance of urban neighbourhood development, which concluded that none of the 21 papers covered all three of the sustainability aspects (economic, environmental and social) to a significant degree [90].

There might be several reasons why certain sustainability aspects are prioritised. One reason is the historic development of indicator use in cities, where the monitoring of environmental degradation (in this case indicators under goal 6 and 15) have received a lot of attention since the 1960s, when industrialisation started to have a major impact on people and environmental awareness in society started to grow $[68,76]$. This history and tradition of monitoring environmental performance also means that the collection of this type of information is relatively easy.

A similar explanation can be used for economic development. The use of GDP as an indicator for economic growth has been established since the 1940s [22]. Despite the fact that there have been numerous attempts to develop other indicators, GDP is so established as an indicator that it is the easy way' to use it as a main indicator to cover the economic aspects of sustainability. The high indicator count for goal 11, on the contrary, can be attributed to the more recent trend of increasing focus on cities as actors to push for sustainable development also on the global level.

Building on past experiences when developing new indicator sets can be seen as a way to continuously improve and adapt the indicator set, however this approach entails the danger of reinforcing a path dependency. As the above example of GDP illustrates, analysing past indicator sets and choosing the ones that 'have been working well previously' can easily lead to the use of established indicators without necessarily reflecting whether these indicators really monitor what is most relevant in current times. It could be argued that it is easier to introduce new aspects to the monitoring of sustainable development than to change well-established indicators. For example, introducing indicators to monitor accessibility to green areas in cities is anticipated to be more easily added to sustainability indicator sets, rather than exchanging the existing indicator of GDP with a measure of non-economic prosperity. Path dependency also shapes methods. Familiarity with quantitative indicators can lead to a misconception that everything can be quantified. Thus, soft aspects of sustainability are most likely to be measured through quantitative indicators, as this is what people are used to, thereby risking overlooking important elements.

\subsection{Anything New with the SDGs?}

Compared to previous indicator sets, the SDG indicators cover aspects that have not been covered before. Sustainable cities (goal 11) and strong institutions (goal 16) are areas that have only recently received attention when assessing sustainable development. As for the ISO 37120 standard, the focus lies predominantly on sustainable cities. This indicator set has cities as its specific target group and hence trying to align the required information to a maximum within this field, resulting in $30 \%$ of all ISO 37120 indicators being repeated under goal 11.

Two areas-gender equality (goal 5) and reduced inequalities within and amongst countries (goal 10) —attract attention for another reason: these aspects have so far not been covered by indicator sets at all or only to a very small degree. These 'soft issues' have presumably been avoided as they are based on underlying societal values that are difficult to question from an outsider's perspective. Furthermore, they are very difficult to isolate and quantify. The SDG indicators do cover these aspects. No poverty (goal 1) and zero hunger (goal 2) are also aspects that have not featured as distinctly in previous indicator sets. They are a legacy from the MDGs and reflect a desire to make the SDGs globally applicable. 
There are a number of areas that the SDG indicators do not cover. In general, the SDG indicators remain on a general level. Examples of this are indicators regarding access to health services. The SDG indicators cover health aspects at a general level, but other indicator sets are more specific, such as the number of hospital beds $/ 100,000$ people or indicators on key diseases. The same is the case for indicators on waste and waste water management or air pollution, where in the SDGs only particulate matter concentrations are required and other air pollutants are summarised in an indicator on mortality rate due to air pollution. Two aspects that seem particularly relevant from an urban perspective are missing, namely the availability and/or accessibility of green recreational areas and the modal split of individual mobility. Voter participation in elections is one aspect that other indicator sets have commonly included but which is missing from the SDG indicators.

The majority of indicators that have previously been used are included in the SDG indicators. However, the SDGs remain more general and overarching and lack a degree of detail. It can be argued that this is due to the fact that the SDGs themselves are meant to follow the logic of 'governance through goal setting' where it is beneficial to stay on a more general level leaving room to specify goals based on the local context [91]. The purpose of following governance through goal setting is to be able to be more inclusive, thereby stimulating action rather than holding parties to account or benchmarking performance. The generic characteristics of the goals have been translated into indicators, but this still creates a need to localise goals, targets and indicators. Of the SDG indicators, it is assumed that the majority are relevant at the city level, although some indicators under the goal 'Reducing inequalities within and amongst countries' (goal 10) can be considered less relevant for cities as they mainly deal with countries' roles in international organisations or money flows between countries.

The challenge of capturing the complexity of urban systems $[12,48]$ and acknowledging system interactions and interrelationships also remains. Assuming that the majority of SDG indicators are relevant on the urban level, a process of localising them, including some form of political prioritisation amongst them, is necessary in order to end up with a policy-relevant indicator set for which reliable data can be collected. It does not necessarily follow that the resulting indicator set will take into account the possible contradictions in the urban system or how factors might influence each other. This challenge has not been addressed in the SDG indicator framework, as it has not been addressed in any robust process for prioritising certain goals or defining goals that need to be met before others [35,92]. The goals and associated indicators are not ranked or weighted and some may even lead to contradictory actions in the short term (such as economic growth/increasing average income and limiting greenhouse gas emissions). This suggests that decision makers need to evaluate what is deemed more important on a case-by-case basis, as has been suggested by some research $[85,93]$, especially in the context of implementing the SDGs at local level [30,45,48,50,51].

The Sustainable Development Solutions Network has developed a guide for stakeholders, "Getting started with the SDGs in cities" [50], outlining steps local governments can take to localise the SDGs. The report highlights some of the challenges identified in this paper, i.e., to "develop an affordable yet comprehensive monitoring and evaluation system effective in reliably capturing progress on local goals and targets". The indicators that the SDGs suggest are all quantitative, and the majority of them are proportional indicators indicating a relation between two variables, such as renewable energy share in the total final energy consumption. There are no indicators that are based on qualitative aspects or that ask for subject valuation, both of which are key to understanding local needs and desires. Examples of qualitative and/or subjective indicators can be found in the Better Life Index developed by the OECD in 2011, and include "How do you judge your health situation?" or "Do you feel safe walking alone at night in the city or area where you live?" More research is needed if qualitative indicators are to complement the SDG indicators by capturing local needs and desires more efficiently than a larger number of quantitative ones. 


\section{Conclusions and Directions for Further Research}

The UN SDGs have been introduced to augment global sustainable development. Although the goals were not intended as a framework to assess sustainable development, they are increasingly being used for this function, especially at the local level. This paper has therefore analysed how the SDGs can advance the assessment and monitoring of urban sustainability, by comparing the SDG indicators with previously developed indicator sets. One of the main differences of the SDG indicators compared to previously used indicator sets is the larger number of indicators in the SDG system.

The SDGs themselves cover sustainability aspects that have not been covered previously, namely aspects of gender equality and reduced inequalities, thereby balancing aspects that have been overly covered in previous indicator sets, such as environmental aspects, aspects of health and aspects of economic growth. Overall, the SDGs may make policy integration across sectors easier [27]. The high number of SDG indicators can facilitate a stronger cooperation across sectors where universities, NGOs and the private and the public sector need to contribute with data to be able to monitor development and thus report in line with the SDG requirements. However, in order to capture the complexity of urban systems, monitoring also needs to include qualitative aspects of development. A number of the SDGs and targets are formulated qualitatively rather than quantitatively. However, it is unclear how far the SDGs and other indicator set cover the qualitative sides of sustainable development. In the process of localising the SDGs, it becomes increasingly important to monitor city-specific conditions, thereby increasing the need to identify relevant qualitative indicators that enable the monitoring of soft aspects of sustainable development.

The analysis also indicated that the idea of an underlying model for human-ecosystem relationship on which to develop the indicators, which was popular in early work on indicator development $[22,61]$ but has been given up. Instead, there seems to be acceptance that a number of important aspects are worth following and decision makers need to prioritise which local conditions are to be monitored.

\section{Recommendations for Future Research}

The study found that the SDG indicators have the potential to monitor urban sustainable development, but that future research needs to analyse and support their practical application in cities. In detail, research needs to be carried out with regard to:

- How the process of articulating the SDG indicators into local urban contexts can be carried out, taking into account the potential for local policy making and political prioritisation

- The potential for quadruple helix cooperation and participation for implementation (reflecting the complexity of urban systems), monitoring and evaluation

- How to identify relevant and achievable targets by long-term, goal-based planning for SDG implementation that counteract short-termism

- Effective and efficient capacity building for practitioners and within academia with regard to local monitoring of SDG implementation

- At what levels of governance the SDG indicators should be applied to deal with externalities and how monitoring might be tested

- Whether the suggested indicators, as they are currently formulated, can be optimised in a specific urban context taking into account different local conditions

- Whether alternative or complementary qualitative indicators are needed that are more relevant at an urban level and able to capture missing aspects.

Author Contributions: Conceptualization, R.Z. and L.N.; Methodology, R.Z. and L.N.; Validation, R.Z., J.E. and L.N.; Formal Analysis, R.Z., J.E. and L.N.; Investigation, R.Z.; Data Curation, R.Z.; Writing-Original Draft Preparation, R.Z., L.N. and J.E.; Writing-Review \& Editing, R.Z., J.E. and L.N.; Visualization, R.Z.; Supervision, L.N. and J.E. 
Funding: This paper is the result of two projects run in cooperation between the Environment Department of the city of Malmö and the International Institute for Industrial Environmental Economics at Lund University: the project NärKom, funded by the Swedish Research Council for Environment, Agricultural Sciences and Spatial Planning, the objective of which is to increase hands-on cooperation between municipalities and academia; and the project Malmö Innovation Arena funded by ERDF, which is a city development project that aims to create innovation that can rapidly, sustainably and cost efficiently boost the implementation of sustainable housing and sustainable city districts. It has also been informed by experiences coordinating the monitoring and assessment of smart solutions for urban sustainability across Manchester, Eindhoven and Stavanger in the Horizon 2020 funded Smart Cities and Communities project, Triangulum (European Union Grant No. 646578, 2014).

Conflicts of Interest: The main author has worked within local government for a long time, resulting in large amounts of tacit knowledge. The research hypothesis, but not the discussion or results, of this paper has been influenced by the current situation and interests in the municipal administration. The funders had no role in the design of the study, in the collection, analyses, or interpretation of data, in the writing of the manuscript, or in the decision to publish the results.

\section{References}

1. UN. United Nations Conference on Environment and Development, Agenda 21; United Nations Division for Sustainable Development: New York, NY, USA, 1992.

2. Barrutia, J.M.; Echebarria, C.; Paredes, M.R.; Hartmann, P.; Apaolaza, V. From Rio to Rio+20: Twenty years of participatory, long term oriented and monitored local planning? J. Clean. Prod. 2015, 106, 594-607. [CrossRef]

3. Graute, U. Local Authorities Acting Globally for Sustainable Development. Reg. Stud. 2016, 50, $1931-1942$. [CrossRef]

4. Brenner, N. Global cities, glocal states: Global city formation and state territorial restructuring in contemporary Europe. Rev. Int. Political Econ. 1998, 5, 1-37. [CrossRef]

5. Van der Pluijm, R.; Melissen, J. City Diplomacy: The Expanding Role of Cities in International Politics; Netherlands Institute of International Relations, Clingendael: Wassenaar, The Netherlands, 2007.

6. Koop, S.H.A.; van Leeuwen, C.J. The challenges of water, waste and climate change in cities. Environ. Dev. Sustain. 2017, 19, 385-418. [CrossRef]

7. Turner, V.K. Obstacles to developing sustainable cities: The real estate rigidity trap. Ecol. Soc. 2017, $22,1$. [CrossRef]

8. Kennedy, C.; Steinberger, J.; Gasson, B.; Hansen, Y.; Hillman, T.; Havránek, M.; Pataki, D.; Phdungsilp, A.; Ramaswami, A.; Mendez, G.V. Greenhouse Gas Emissions from Global Cities. Environ. Sci. Technol. 2009, 43, 7297-7302. [CrossRef] [PubMed]

9. Wuppertal Institute for Climate Environment and Energy. Sustainable Urban Infrastructure-Paths toward a Carbon-Free Future. Available online: http://www.mobility.siemens.com/mobility/global/ SiteCollectionDocuments/en/sustainable-munich-2009-en.pdf (accessed on 18 July 2017).

10. Angelidou, M.; Psaltoglou, A. An empirical investigation of social innovation initiatives for sustainable urban development. Sustain. Cities Soc. 2017, 33, 113-125. [CrossRef]

11. Hodson, M.; Geels, F.W.; McMeekin, A. Reconfiguring Urban Sustainability Transitions, Analysing Multiplicity. Sustainability 2017, 9, 299. [CrossRef]

12. Leach, J.M.; Braithwaite, P.A.; Lee, S.E.; Bouch, C.J.; Hunt, D.V.L.; Rogers, C.D.F. Measuring urban sustainability and liveability performance: The City Analysis Methodology. Int. J. Complex. Appl. Sci. Technol. 2016, 1, 86-106. [CrossRef]

13. UN. New Urban Agenda. In Proceedings of the United Nations Habitat III, Quito, Ecuador, 17-20 October 2016.

14. Yigitcanlar, T. Smart cities: An effective urban development and management model? Aust. Plan. 2015, 52, 27-34. [CrossRef]

15. UN. World Urbanization Prospects: The 2014 Revision, Highlights; United Nations, Department of Economic and Social Affairs, Population Division: New York, NY, USA, 2014.

16. Bibri, S.E.; Krogstie, J. Smart sustainable cities of the future: An extensive interdisciplinary literature review. Sustain. Cities Soc. 2017, 31, 183-212. [CrossRef]

17. Wilson, J.; Tyedmers, P.; Pelot, R. Contrasting and comparing sustainable development indicator metrics. Ecol. Indic. 2007, 7, 299-314. [CrossRef]

18. Bell, S.; Morse, S. Measuring Sustainability_Learning from Doing; Earthscan: London, UK, 2003; ISBN 1-85383-843-8. 
19. Bunge, M. What is a quality of life indicator? Soc. Indic. Res. 1975, 2, 65-79. [CrossRef]

20. Horsch, K. Indicators: Definition and Use in a Results-Based Accountability System. Available online: http:/ / www.hfrp.org/publications-resources/publications-series/reaching-results/indicators-definitionand-use-in-a-results-based-accountability-system (accessed on 27 May 2016).

21. Cobb, C.W.; Rixford, C. Lessons Learned from the History of Social Indicators; Redefining Progress: San Francisco, CA, USA, 1998.

22. Hodge, T. Towards a conceptual framework for assessing progress toward sustainability. Soc. Indic. Res. 1997, 40, 5-98. [CrossRef]

23. Munn, R.; Alcamo, J.; Fedorov, V. Evaluating the Performance of Air-Quality Models in a Policy Framework. Syst. Anal. Model. Simul. 1988, 5, 493-510.

24. Kitchin, R.; Lauriault, T.P.; McArdle, G. Knowing and governing cities through urban indicators, city benchmarking and real-time dashboards. Reg. Stud. Reg. Sci. 2015, 2, 6-28. [CrossRef]

25. Petit-Boix, A.; Llorach-Massana, P.; Sanjuan-Delmas, D.; Sierra-Perez, J.; Vinyes, E.; Gabarrell, X.; Rieradevall, J.; Sanye-Mengual, E. Application of life cycle thinking towards sustainable cities: A review. J. Clean. Prod. 2017, 166, 939-951. [CrossRef]

26. Hák, T.; Janoušková, S.; Moldan, B. Sustainable Development Goals: A need for relevant indicators. Ecol. Indic. 2016, 60, 565-573. [CrossRef]

27. Le Blanc, D. Towards Integration at Last? The Sustainable Development Goals as a Network of Targets. Sustain. Dev. 2015, 23, 176-187. [CrossRef]

28. UN. Transforming Our World: The 2030 Agenda for Sustainable Development; Resolution Adopted by the General Assembly on 25 September 2015; UN: New York, NY, USA, 2015.

29. Morton, S.; Pencheon, D.; Squires, N. Sustainable Development Goals (SDGs), and their implementationA national global framework for health, development and equity needs a systems approach at every level. Br. Med. Bull. 2017, 124, 81-90. [CrossRef] [PubMed]

30. Stafford-Smith, M.; Griggs, D.; Gaffney, O.; Ullah, F.; Reyers, B.; Kanie, N.; Stigson, B.; Shrivastava, P.; Leach, M.; O'Connell, D. Integration: The key to implementing the Sustainable Development Goals. Sustain. Sci. 2017, 12, 911-919. [CrossRef] [PubMed]

31. UN. I-AEG on SDG Indicators 4th Meeting of the Inter-Agency and Expert Group on Sustainable Development Goal Indicators (IAEG-SDGs). Available online: http://unstats.un.org/sdgs/files/meetings/iaeg-sdgsmeeting-04/9.\%20Refinement\%20of\%20Indicators\%20plenary.pdf (accessed on 20 December 2016).

32. UN. Global Indicator Framework; United Nations Statistics Division: New York, NY, USA, 2017.

33. Filho, W.L.; Azeiteiro, U.; Alves, F.; Pace, P.; Mifsud, M.; Brandli, L.; Caeiro, S.S.; Disterheft, A. Reinvigorating the sustainable development research agenda: The role of the sustainable development goals (SDG). Int. J. Sustain. Dev. World Ecol. 2018, 25, 131-142. [CrossRef]

34. Kumar, S.; Kumar, N.; Vivekadhish, S. Millennium Development Goals (MDGs) to Sustainable Development Goals (SDGs): Addressing Unfinished Agenda and Strengthening Sustainable Development and Partnership. Indian J. Community Med. Off. Publ. Indian Assoc. Prev. Soc. Med. 2016, 41, 1-4. [CrossRef] [PubMed]

35. Holden, E.; Linnerud, K.; Banister, D. The Imperatives of Sustainable Development. Sustain. Dev. 2017, 25, 213-226. [CrossRef]

36. Reyers, B.; Stafford-Smith, M.; Erb, K.-H.; Scholes, R.J.; Selomane, O. Essential Variables help to focus Sustainable Development Goals monitoring. Curr. Opin. Environ. Sustain. 2017, 26, 97-105. [CrossRef]

37. Rickels, W.; Dovern, J.; Hoffmann, J.; Quaas, M.F.; Schmidt, J.O.; Visbeck, M. Indicators for monitoring sustainable development goals: An application to oceanic development in the European Union. Earth's Future 2016, 4, 252-267. [CrossRef]

38. Barnett, C.; Parnell, S. Ideas, implementation and indicators: Epistemologies of the post-2015 urban agenda. Environ. Urban. 2016, 28, 87-98. [CrossRef]

39. Sustainable Development Solutions Network. Indicators and a Monitoring Framework for the Sustainable Development Goals_Launching a Data Revolution for the SDGs; Sustainable Development Solutions Network: New York, NY, USA, 2015.

40. Arfvidsson, H.; Simon, D.; Oloko, M.; Moodley, N. Engaging with and measuring informality in the proposed Urban Sustainable Development Goal. Afr. Geogr. Rev. 2016, 36, 100-114. 
41. Arslan, T.V.; Durak, S.; Aytac, D.O. Attaining SDG11: Can sustainability assessment tools be used for improved transformation of neighbourhoods in historic city centers? Nat. Resour. Forum 2016, 40, 180-202. [CrossRef]

42. Cohen, M. A Systematic Review of Urban Sustainability Assessment Literature. Sustainability 2017, 9, 2048. [CrossRef]

43. Corbett, J.; Mellouli, S. Winning the SDG battle in cities: How an integrated information ecosystem can contribute to the achievement of the 2030 sustainable development goals. Inf. Syst. J. 2017, 27, 427-461. [CrossRef]

44. Kharrazi, A.; Qin, H.; Zhang, Y. Urban big data and sustainable development goals: Challenges and opportunities. Sustainability 2016, 8, 1293. [CrossRef]

45. Klopp, J.M.; Petretta, D.L. The urban sustainable development goal: Indicators, complexity and the politics of measuring cities. Cities 2017, 63, 92-97. [CrossRef]

46. Koch, F.; Ahmad, S. How to Measure Progress Towards an Inclusive, Safe, Resilient and Sustainable City? Reflections on Applying the Indicators of Sustainable Development Goal 11 in Germany and India. In Urban Transformations; Future City; Springer: Cham, Switzerland, 2018; pp. 77-90. ISBN 978-3-319-59323-4.

47. Parnell, S. Defining a Global Urban Development Agenda. World Dev. 2016, 78, 529-540. [CrossRef]

48. Patel, Z.; Greyling, S.; Simon, D.; Arfvidsson, H.; Moodley, N.; Primo, N.; Wright, C. Local responses to global sustainability agendas: Learning from experimenting with the urban sustainable development goal in Cape Town. Sustain. Sci. 2017, 12, 785-797. [CrossRef] [PubMed]

49. Simon, D.; Arfvidsson, H.; Anand, G.; Bazaz, A.; Fenna, G.; Foster, K.; Jain, G.; Hansson, S.; Evans, L.M.; Moodley, N.; et al. Developing and testing the Urban Sustainable Development Goal's targets and indicators-A five-city study. Environ. Urban. 2016, 28, 49-63. [CrossRef]

50. Kanuri, C.; Revi, A.; Espey, J.; Kuhle, H. Getting Started with the SDGs in Cities; Sustainable Development Solutions Network: New York, NY, USA, 2016.

51. United Cities and Local Governments (UCLG). The Sustainable Development Goals—What Local Governments Need to Know; UCLG: Barcelona, Spain, 2015.

52. Pupphachai, U.; Zuidema, C. Sustainability indicators: A tool to generate learning and adaptation in sustainable urban development. Ecol. Indic. 2017, 72, 784-793. [CrossRef]

53. Baynes, T.M.; Wiedmann, T. General approaches for assessing urban environmental sustainability. Curr. Opin. Environ. Sustain. 2012, 4, 458-464. [CrossRef]

54. Huang, L.; Wu, J.; Yan, L. Defining and measuring urban sustainability: A review of indicators. Landsc. Ecol. 2015, 30, 1175-1193. [CrossRef]

55. Mori, K.; Christodoulou, A. Review of sustainability indices and indicators: Towards a new City Sustainability Index (CSI). Environ. Impact Assess. Rev. 2012, 32, 94-106. [CrossRef]

56. Hermans, L.M.; Naber, A.C.; Enserink, B. An approach to design long-term monitoring and evaluation frameworks in multi-actor systems-A case in water management. Eval. Program Plan. 2012, 35, 427-438. [CrossRef] [PubMed]

57. Holden, M. Sustainability indicator systems within urban governance: Usability analysis of sustainability indicator systems as boundary objects. Ecol. Indic. 2013, 32, 89-96. [CrossRef]

58. McPhearson, T.; Parnell, S.; Simon, D.; Gaffney, O.; Elmqvist, T.; Bai, X.; Roberts, D.; Revi, A. Scientists must have a say in the future of cities. Nat. News 2016, 538, 165-166. [CrossRef] [PubMed]

59. Monaco, E. Sustainable Development Governance from Margins to Mainstream: Overcoming Traps by Embracing Complexity. Eur. J. Sustain. Dev. 2018, 7, 25-32. [CrossRef]

60. Bossel, H. Indicators for Sustainable Development: Theory, Method, Applications; IISD: Winnipeg, MB, Canada, 2001.

61. Mineur, E. Towards Sustainable Development_Indicators as a Tool of Local Governance; Department of Political Science, Umeå University: Umeå, Sweden, 2007; ISBN 978-91-7264-416-8.

62. Singh, R.K.; Murty, H.R.; Gupta, S.K.; Dikshit, A.K. An overview of sustainability assessment methodologies. Ecol. Indic. 2009, 9, 189-212. [CrossRef]

63. Niemeijer, D.; de Groot, R. A conceptual framework for selecting environmental indicator sets. Ecol. Indic. 2008, 8, 14-25. [CrossRef]

64. Astleithner, F.; Hamedinger, A.; Holman, N.; Rydin, Y. Institutions and indicators-The discourse about indicators in the context of sustainability. J. Hous. Built Environ. 2004, 19, 7-24. [CrossRef] 
65. Luederitz, C.; Schäpke, N.; Wiek, A.; Lang, D.J.; Bergmann, M.; Bos, J.J.; Burch, S.; Davies, A.; Evans, J.; König, A.; et al. Learning through evaluation-A tentative evaluative scheme for sustainability transition experiments. J. Clean. Prod. 2017, 169, 61-76. [CrossRef]

66. Organization for Economic Co-operation and Development (OECD). Handbook on Constructing Composite Indicators; OECD: Paris, France, 2008; ISBN 978-92-64-04345-9.

67. Wong, C. Indicators for Urban and Regional Planning; The RTPI Library Series; Routledge: New York, NY, USA, 2006; Volume 2006, ISBN 978-0-415-27451-7.

68. Böhringer, C.; Jochem, P.E.P. Measuring the immeasurable-A survey of sustainability indices. Ecol. Econ. 2007, 63, 1-8. [CrossRef]

69. Ness, B.; Urbel-Piirsalu, E.; Anderberg, S.; Olsson, L. Categorising tools for sustainability assessment. Ecol. Econ. 2007, 60, 498-508. [CrossRef]

70. Science for Environment Policy. Indicators for Sustainable Cities; European Commission DF Environment by the Science Communication Unit: Brussels, Belgium, 2015.

71. Keirstead, J.; Leach, M. Bridging the gaps between theory and practice: A service niche approach to urban sustainability indicators. Sustain. Dev. 2008, 16, 329-340. [CrossRef]

72. Shen, L.-Y.; Jorge, O.; Shah, M.N.; Zhang, X. The application of urban sustainability indicators-A comparison between various practices. Habitat Int. 2011, 35, 17-29. [CrossRef]

73. Lehtonen, M.; Sébastien, L.; Bauler, T. The multiple roles of sustainability indicators in informational governance: Between intended use and unanticipated influence. Curr. Opin. Environ. Sustain. 2016, 18, 1-9. [CrossRef]

74. Rowe, G.; Frewer, L.J. Public Participation Methods: A Framework for Evaluation. Sci. Technol. Hum. Values 2000, 25, 3-29. [CrossRef]

75. Neumann, H.-M.; Jakutyte-Walangitang, D.; Vielguth, S.; Züger, J.; Airaksinen, M.; Huovila, A.; Bosch, P.; Rovers, V.; Jongeneel, S.; Pangerl, E. Overview of the Current State of the Art. Available online: http:/ / nws.eurocities.eu/MediaShell/media/D1.2\%20Overview $\% 20$ of $\% 20$ the $\% 20$ Current $\% 20 S t a t e \%$ 20of\%20the\%20Art.pdf (accessed on 20 December 2016).

76. Tanguay, G.A.; Rajaonson, J.; Lefebvre, J.-F.; Lanoie, P. Measuring the sustainability of cities: An analysis of the use of local indicators. Ecol. Indic. 2010, 10, 407-418. [CrossRef]

77. Vázquez, P.; del Río, J.A.; Cedano, K.G.; Martínez, M.; Jensen, H.J. An Entangled Model for Sustainability Indicators. PLoS ONE 2015, 10, e0135250. [CrossRef] [PubMed]

78. UN. Habitat UN Habitats Urban Indicator Programme. Available online: https://unhabitat.org/urbanindicators-guidelines-monitoring-the-habitat-agenda-and-the-millennium-development-goals/\# (accessed on 30 May 2018).

79. Commission for Sustainable Development. Commission for Sustainable Development's Sustainable Development Indicators. Available online: http://www.un.org/esa/sustdev/natlinfo/indicators/ guidelines.pdf (accessed on 30 May 2018).

80. European Union. EU's Urban Sustainability Indicators. Available online: http:/ / edz.bib.uni-mannheim.de/ www-edz/pdf/ef/98/ef9807en.pdf (accessed on 30 May 2018).

81. European Union. European Common Indicators. Available online: https://www.gdrc.org/uem/footprints / eci_final_report.pdf (accessed on 30 May 2018).

82. OECD. Better Life Index. Available online: http:/ / www.oecdbetterlifeindex.org/ (accessed on 30 May 2018).

83. International Standards Organization. ISO 37120 Smart City Data. Available online: http://www. dataforcities.org/wccd/ (accessed on 30 May 2018).

84. UN. SDG Indicators. Available online: http://unstats.un.org/sdgs/indicators/indicators-list/ (accessed on 20 December 2016).

85. Rivera, M. Political Criteria for Sustainable Development Goal (SDG) Selection and the Role of the Urban Dimension. Sustainability 2013, 5, 5034-5051. [CrossRef]

86. Scott, A.; Lucci, P. Universality and Ambition in the Post-2015 Development Agenda: A Comparison of Global and National Targets. J. Int. Dev. 2015, 27, 752-775. [CrossRef]

87. UN. SDG Indicators-UN Statistical Division. Available online: https://unstats.un.org/sdgs/dataContacts / (accessed on 22 May 2018).

88. Alter, K.J.; Meunier, S. The Politics of International Regime Complexity. Perspect. Politics 2009, 7, 13-24. [CrossRef] 
89. Bakhtiari, F. International cooperative initiatives and the United Nations Framework Convention on Climate Change. Clim. Policy 2018, 18, 655-663. [CrossRef]

90. Luederitz, C.; Lang, D.J.; Von, W. A systematic review of guiding principles for sustainable urban neighborhood development. Landsc. Urban Plan. 2013, 118, 40-52. [CrossRef]

91. Biermann, F.; Kanie, N.; Kim, R.E. Global governance by goal-setting: The novel approach of the UN Sustainable Development Goals. Curr. Opin. Environ. Sustain. 2017, 26-27, 26-31. [CrossRef]

92. Griggs, D.; Stafford-Smith, M.; Gaffney, O.; Rockström, J.; Öhman, M.C.; Shyamsundar, P.; Steffen, W.; Glaser, G.; Kanie, N.; Noble, I. Policy: Sustainable Development Goals for People and Planet. Available online: https: / / www.nature.com/articles/495305a (accessed on 9 April 2018).

93. Mascarenhas, A.; Nunes, L.M.; Ramos, T.B. Selection of sustainability indicators for planning: Combining stakeholders' participation and data reduction techniques. J. Clean. Prod. 2015, 92, 295-307. [CrossRef]

2018 by the authors. Licensee MDPI, Basel, Switzerland. This article is an open access article distributed under the terms and conditions of the Creative Commons Attribution (CC BY) license (http://creativecommons.org/licenses/by/4.0/). 